\title{
Magnetic studies and scanning electron microscopy - x-ray energy dispersive spectroscopy analyses of road sediments, soils and vehicle-derived emissions
}

Marcos A.E. Chaparro ${ }^{1 *}$, Débora C. Marié ${ }^{1,2}$, Claudia S.G. Gogorza ${ }^{1}$, Ana NAvas ${ }^{3}$, ANA M. SINITO ${ }^{1}$

1 Instituto de Física Arroyo Seco (UNCPBA)-CONICET, Pinto 399, B7000GHG Tandil, Argentina.

2 Universidad Nacional de Mar del Plata (UNMdP), Deán Funes 3350, 7600 Mar del Plata,

Argentina.

3 Estación Experimental de Aula Dei, CSIC, Apartado 13034, 50080 Zaragoza, España.

In original form 5 March, 2010. Revised form 27 May, 2010. Accepted 1 June, 2010.

Abbreviated title for page heading:

Magnetic and SEM-EDS studies of vehicle-derived pollutants

* Name and contact detail of the corresponding author:

Marcos A.E. Chaparro. Instituto de Física Arroyo Seco (UNCPBA), Pinto 399, B7000GHG Tandil, Argentina.

Phone: +54 2293 439661; Fax: +54 2293439669

E-mail: chapator@exa.unicen.edu.ar 


\section{Abstract}

Human health and environmental problems related to particulate matter emission from vehicles has become a topic of research interest in recent years. These airborne particles can not only be directly inhaled, but are also present as suspended and deposited particles on paved areas and roadside soils. Here we report on magnetic studies, scanning electron microscopy, x-ray energy dispersive spectroscopy and chemical analyses of vehicle-derived particles collected from both primary sources and as deposited particles on roads and soils. Preliminary results, recently published by the authors, have revealed that the magnetic signal of such particles is controlled by a magnetite-like phase with magnetic grain size ranging between $0.1 \mu \mathrm{m}$ and $5 \mu \mathrm{m}$. An enrichment of some trace elements: $\mathrm{Ba}, \mathrm{Cr}, \mathrm{Cu}, \mathrm{Zn}$ and $\mathrm{Pb}$ was also found. In this study we focus on SEM and EDS complementary studies of magnetic extracts. SEM observations showed small individual particles or spherulites, small aggregates in the form of chains or clusters, large aggregates of spherules, flake-like bodies, fibre-like particles, sheet-like particles, irregular debris and large particle agglomerates, i.e. a wide variety of shapes. Grain size distribution is also in agreement with magnetic grain size estimations. Additionally the following elements: C, O, Na, Mg, Al, Si, S, K, Ca, V, Ba, Ti, $\mathrm{Cr}, \mathrm{Mn}, \mathrm{Fe}, \mathrm{Cu}, \mathrm{Zn}$ and $\mathrm{Pb}$ were detected by EDS analysis.

Keywords: atmospheric pollution, diesel/gas soot, magnetic proxies, PM vehicle emissions, wear particles 


\section{Introduction}

Vehicle emissions are seen as a significant pollution source in urban areas, comprising particles formed in the engine and wear particles from tyres and brake materials. Such emissions include different size fractions from sub-micron to micron, including: ultrafine particles $(<30 \mathrm{~nm}, 30-100 \mathrm{~nm})$ formed in the engine, the exhaust pipe or immediately after emission; fine particles $(0.1-2 \mu \mathrm{m})$ formed by chemical reactions or other processes and coarse mode particles $(>2 \mu \mathrm{m})$ formed by the mechanical abrasion of road surface, tyre and brake materials (Palmgren et al., 2003).

In terms of aerodynamic diameter, the particulate matter (PM) can also be classified as fine particles $(<2.5 \mu \mathrm{m})$, inhalable particles $(<10 \mu \mathrm{m})$ and total suspended particles $(<30$ or 100 $\mu \mathrm{m})$. These particles not only impact on environments, but can also be deeply inhaled and are therefore dangerous to human health. According to Rizzio et al. (1999), grains $<4.6 \mu \mathrm{m}$ are especially dangerous to humans as they can be inhaled into the bronchial region, while even more harmful are grains $<1.1 \mu \mathrm{m}$ which can be deposited in the alveoli. Some studies have shown that long-term exposure to these particles can lead to respiratory and cardiovascular diseases (e.g. Pope et al., 2002; Knutsen et al., 2004; Knox, 2006; Pope and Dockery 2006).

Different authors (Flanders, 1994; Kasper et al., 1999; Abdul-Razzaq and Gautam, 2001; Kim et al., 2007) have reported the presence of magnetic particles in the PM of vehicle emissions. These magnetic particles are not only important because of their relationship with heavy metals but also because of their adverse influence on human health. Such magnetic particles can be inhaled and absorbed in human tissues, which has potential implications for many biomedical issues, including human exposure to the strong static magnetic field used in magnetic resonance imaging, as well as to weaker fields produced by electric power systems and cell phones (Kirschvink et al., 1992). The presence of magnetite in tissues can also cause severe tissue damage, as considerable heat is induced - magnetic thermoablation - when an 
alternating magnetic field is applied. This process has not only heat-induced but also cytotoxic effects (Hilger et al., 2003).

Although articles concerning traffic-related magnetic monitoring have increased recently (Amereih et al., 2005; Zhang et al., 2006; Kim et al., 2007; Maher et al., 2008), there remains a scarcity of magnetic studies of primary sources, such as PM emissions from exhaust pipes (Lu et al., 2005) or wear particles from the brake systems of vehicles. Such information is not only useful for basic knowledge of primary emissions, but also for the identification of different contamination sources from vehicles and their influence.

Preliminary results focussing on magnetic and chemical studies have recently been published by Marié et al. (2010). In this study, we present results from another tollbooth site, concentrating on the magnetic properties of primary pollutants generated by vehicles, as well as on scanning electron microscopy (SEM) and x-ray energy dispersive spectroscopy (EDS) studies of magnetic extracts in the investigation of morphologies and associated trace elements.

\section{Methods and sampling}

\section{$\underline{2.1 \text { Sampling }}$}

Samples were collected from the exhaust pipes of several vehicles with gasoline and dieselpowered engines, as well as from their brake systems. Samples were also collected from roaddeposited sediments in tollbooth areas (Maipu, $M$ and Samborombon, SB) and from roadside soils along Autovia 2 (Buenos Aires province, Argentina) during two sampling campaigns. For sampling sites and further details, the readers are referred to Marié et al. (2010).

Each sample was carefully collected using plastic scrapers and tools to avoid contamination. Among the sediments, scraped samples were identified as $C M$ (collected from the Maipu tollbooth area), SM (collected from the Maipu vehicle braking/accelerating area) and $R S B$ 
(collected from the Samborombon tollbooth area), while swept sediments samples were classified as $L M$ (from Maipu) and LSB (from Samborombon). Soil samples were identified as MP (collected from roadside soils between Maipu and Mar del Plata City), and samples collected from primary pollution sources (vehicles) as diesel, gas (PM collected from vehicle exhaust emissions) and brake (wear particles generated from brake materials).

\section{$\underline{2.2 \text { Methods }}$}

Magnetic measurements were carried out in the palaeomagnetic laboratory of the IFASUNCPBA (Tandil, Argentina). Several rock-magnetic measurements were done, including magnetic susceptibility $(\kappa)$ and anhysteretic and isothermal remanent magnetisation (ARM and IRM). As detailed in Marié et al. (2010), magnetic susceptibility measurements were carried out using a magnetic susceptibility meter (MS2, Bartington Instruments Ltd) connected to the MS2B dual frequency sensor (470 and $4700 \mathrm{~Hz}$ ). ARM was imparted by superimposing a DC field of $90 \mu \mathrm{T}$ to an AF of $100 \mathrm{mT}$, using a partial ARM (pARM) device attached to a shielded demagnetizer (Molspin Ltd). IRM (acquisition and backfield) studies were carried out with an ASC Scientific model IM-10-30 pulse magnetizer. The remanent magnetisation after each step for ARM and IRM studies was measured by a Molspin Ltd. Minispin fluxgate spinner magnetometer. Several related magnetic parameters, ratios and plots were obtained and analysed: mass-specific magnetic susceptibility $(\chi)$; anhysteretic susceptibility $\left(\kappa_{\mathrm{ARM}}\right) ; \kappa_{\mathrm{ARM}} / \kappa$ ratio; saturation of IRM $(\mathrm{SIRM}) ; \mathrm{S}-$ ratio $\left(-\mathrm{IRM}_{-300 \mathrm{mT}} / \mathrm{SIRM}\right)$; remanent coercivity $(\mathrm{Hcr})$ and $\mathrm{SIRM} / \kappa$ ratio.

Some samples were homogenised, quartered and prepared for chemical analysis. To eliminate any organic matter, samples were chemically disaggregated with $10 \% \mathrm{H}_{2} \mathrm{O}_{2}$, heated to $80^{\circ} \mathrm{C}$, stirred and dispersed in an ultrasonic bath. Analysis of total elemental composition was carried out after total acid digestion with HF (48\%) in a microwave oven. The analytical methods are described in detail in Navas and Machín (2002). Samples were analysed for the 
following 17 elements: Li, K, Na, Mg, Ca, Sr, Ba, Cr, Mn, Fe, Co, Ni, Cu, Al, Zn, Cd and Pb. Analyses were performed by optic emission spectrometry using an inductively-coupled plasma ICP-OES (solid state detector). Concentrations, obtained after three measurements per element, are expressed in $\mathrm{mg} / \mathrm{kg}$. Detection limits for the trace elements are: $\mathrm{Cr}: 45 \mathrm{ppb} ; \mathrm{Cu}$, $\mathrm{Zn}$ and $\mathrm{Pb}$ : 55 ppb; Co: 40 ppb; Ni: 60 ppb and Cd: 25 ppb. The Tomlinson pollution load index (PLI, Tomlinson et al., 1980) was also calculated using these element determinations. This index indicates to what extent a sample exceeds the heavy metal content for natural environments. PLI is defined as the $n$th root of the multiplication of concentration factors $\left(C F_{k}\right)$, i.e.

$P L I=\sqrt[n]{\prod_{k=1}^{n} C F_{k}}$, where $C F_{k}$ is the ratio of the content of each heavy metal $\left(\mathrm{C}_{\mathrm{HM}, \mathrm{k}}\right)$ to the baseline value $\left(\mathrm{C}_{\text {baseline, } \mathrm{k}}\right)$ (the lowest concentration values detected for each heavy metal in the study area).

Several samples were also prepared for the analysis of magnetic extracts, for which they were examined by SEM using a JEOL JSM-6460LV microscope. Magnetic extraction for representative samples was performed using a hand magnet; the dry (sieved) material fraction was then dispersed and separated from the non-magnetic fraction. Before SEM observation, each specimen was prepared with a thin coating of $\mathrm{Au} / \mathrm{Pd}$. The composition was finally analyzed by EDS investigation. The system used was an EDAX Genesis XM4 - Sys 60, equipped with Multichannel Analyzer EDAX mod EDAM IV, Sapphire Si(Li) detector and Be Super Ultra Thin Window running EDAX Genesis version 5.11 software.

\section{Results and discussion}

\section{$\underline{3.1 \text { Magnetic parameters }}$}


Analysis of magnetic parameters suggests that the magnetic signal of vehicle-derived emissions is controlled by a ferrimagnetic phase, especially that of magnetite-like minerals (Table 1). Such a conclusion can be drawn from the high S-ratio $(>0.90)$ and Hcr values (6.1$39.8 \mathrm{mT}$ ) belonging to the range of magnetite (Peters and Dekkers, 2003). These parameters show similar values for gas and diesel samples, while brake samples have higher S-ratio and lower Hcr values. Values of scraped, swept and soil samples vary only slightly, with mean Hcr values of about $36 \mathrm{mT}, 34 \mathrm{mT}$ and $35 \mathrm{mT}$, respectively.

Although the grain size-dependent parameters (SIRM $/ \kappa$ and $\kappa_{\mathrm{ARM}} / \kappa$ ratio) show differences among samples, magnetic grain size estimations reveal in all samples the presence of fine particles $(0.1-5 \mu \mathrm{m})$ that can be inhaled. Diesel and gas samples show higher values of the aforementioned parameters than brake samples, hence a trend to a finer magnetic grain size is concluded for soot samples. Among the remaining classes, scraped samples trend to a coarser size than swept and soil samples.

The concentration-dependent parameters ( $\chi$, ARM and SIRM) of gas and brake samples are very high (about three times those of sediment/soil samples), which is expected for these kinds of sample. Contrastingly, parameters of diesel samples are lower than gas and brake samples. Among sediment and soil samples, the highest magnetic concentration values were seen in scraped sediments and the lowest in soil samples (Table 1).

\section{$\underline{3.2 \text { Elemental analysis }}$}

Chemical analyses (Table 1) show variability between the different samples and an enrichment of some trace elements - such as $\mathrm{Ba}, \mathrm{Cr}, \mathrm{Cu}, \mathrm{Co}, \mathrm{Zn}$ and $\mathrm{Pb}$ - that is associated with traffic pollution. Since these elements are present naturally in the environment, the contribution of wind-borne particles from soils should be considered. The obtained values for the different elements are all above baseline values (Table 1), which were defined from studies of regional soils - Typic, Vertic and Aquic Argiudolls, Typic Natraqualfs, Mollic 
Natrudalfs, Typic Natraquolls, Typic Natrudolls - according to Lavado et al. (2004) and Chaparro et al. (2004). Besides this background source, metal-based additives are also present in fuels and lubricating oils. For example, $\mathrm{Ba}$ in diesel fuel is used as a smoke suppressant, $\mathrm{Mn}$ is used as an anti-knock agent, while $\mathrm{Zn}, \mathrm{Ca}, \mathrm{Mg}$ and other metal-based additives are used to minimize the damaging effect of residual complexes - after combustion, metal complexes may remain as deposits in an engine combustion chamber - in engine wear and corrosion (Huhn et al., 1995; Lim et al., 2007).

High concentrations of $\mathrm{Ba}, \mathrm{Cr}, \mathrm{Cu}, \mathrm{Zn}$ and $\mathrm{Pb}$ were found in sediment and soil samples from Samborombon and Maipu, surpassing corresponding baseline values by between three and thirteen times (Table 1). Although soils may be influenced by different pollution sources (industrial activities, agrochemical products used in agriculture, untended waste dumps and urban activities), the nearest examples of these are located far from the study site. Therefore vehicle-derived emissions are the only likely pollution sources in this area (soils and tollbooth) and as such elemental abundances can be interpreted as a direct consequence of this particular anthropogenic activity. These elements have previously been reported in other traffic-related studies (Weckwerth, 2001; Wang et al., 2003; Lin et al., 2005). In contrast, concentrations of $\mathrm{Cd}$ (with the exception of brake and scraped samples) and Co are below baseline values, at $0.8 \mathrm{mg} / \mathrm{kg}$ and $34.8 \mathrm{mg} / \mathrm{kg}$, respectively.

For these samples, $\mathrm{Cr}, \mathrm{Cu}, \mathrm{Zn}$ and $\mathrm{Cd}$ values show a similar trend to magnetic concentration. Conversely, $\mathrm{Ba}, \mathrm{Co}$ and $\mathrm{Pb}$ values display the opposite, with samples showing the highest metal content having the lowest magnetic concentration. It is worth mentioning that $\mathrm{Pb}$ concentrations are the highest of any metal in the soil samples. This is an interesting, since soil $\mathrm{Pb}$ concentration is not only higher than that of brake samples, but also than scraped and swept samples. One possible explanation may be linked to a decrease in the lead content of fuel during recent years. Swept and scraped sediments represent relatively recent 
contributions, while soils may contain the metal input over a longer time scale, i.e. including contributions from previous years of leaded fuel usage. The metal, once it is deposited in the soil can be less mobile and may accumulate on the surface, being retained, dissolved in soil solution or fixed by adsorption or precipitation.

Concentrations of $\mathrm{Cr}, \mathrm{Cu}, \mathrm{Zn}$ and $\mathrm{Cd}$ are much higher in brake samples than in sediment/soil samples. This result is expected, since brake samples represent collection from a primary pollution source.

Trace element enrichment can also be appreciated from the PLI (PLI 1 for unpolluted samples), a measure of the central tendency of the heavy metal data. These values are shown in Table 1. Although they are higher for scraped (between 2.7 and 4.3) than for swept (between 1.4 and 3.6) and soil samples (between 1.9 and 3.1), PLI values of brake samples are by far the highest, by one order of magnitude (11.6-14.9).

\section{$\underline{3.3 \text { SEM and EDS analysis }}$}

SEM observations of magnetic extracts from the primary pollution sources are illustrated in Figs. 1, 2 and 3. Such pollutants, namely PM emission of gasoline/diesel-powered vehicles and wear particles generated from brake materials, were studied to confirm the presence of different elements.

The results obtained from magnetic extracts of diesel samples are shown in Fig. 1 and Table 2. SEM analysis indicates the presence of agglomerates of small particles. The enlarged images reveal ultrafine and fine particles $(<1 \mu \mathrm{m})$, which is in agreement with the grain size distribution and basic morphologies of diesel emissions (Berube et al., 1999). These particles were composed of: small individual particles or spherulites $(\sim 30 \mathrm{~nm})$; small aggregates in the form of chains or clusters; large aggregates of spherules $(1-2 \mu \mathrm{m})$ and flake-like bodies (0.5$2.5 \mu \mathrm{m})$. The observed grain sizes shown in Fig. 1 are also consistent with those estimated using the King's plot $(0.1-5 \mu \mathrm{m})$ in this study. It is worth mentioning that EDS analysis 
indicates a predominance of $\mathrm{C}$, with lower proportions of $\mathrm{O}, \mathrm{Mg}, \mathrm{Al}, \mathrm{S}, \mathrm{Fe}, \mathrm{Cu}$ and $\mathrm{Zn}$ (Table 2; major elemental contributions for each area highlighted). A higher proportion of iron should be expected (for magnetic extracts), but the carbon results can be explained by the high production of carbonaceous primary particles in diesel combustion, especially as carbon covers the surface of iron oxides (Kasper et al., 1999; Yao et al., 2009).

SEM images obtained from gas samples (PM from gasoline-powered engines) can be observed in Fig. 2. These show larger agglomerates (than found in diesel samples) of spherulites and irregular particles, as well as spherules of about $10 \mu \mathrm{m}$ with aggregates of smaller flake-like particles $(<2 \mu \mathrm{m})$. These results are in agreement with the magnetic analysis (Table 1). EDS analysis shows the dominance of $\mathrm{C}, \mathrm{O}$ and $\mathrm{Fe}$ and to a lesser extent, $\mathrm{Na}, \mathrm{Si}, \mathrm{P}, \mathrm{S}, \mathrm{Ca}, \mathrm{Fe}$ and $\mathrm{Zn}$. Other elements were also detected, but in lower amounts (Table 2). Most of these elements have also been reported in previous studies by other authors (e.g.: Geller et al., 2006; Vouitsis et al., 2009).

Results from the remaining primary pollution source, the magnetic extracts of brake samples, are shown in Fig. 3. These SEM studies indicate the presence of wear particles of varied grain size and morphology: fibre-like particles; sheet-like particles; irregular debris and large particle agglomerates. The enlarged images show agglomerates of micron-sized particles with aggregates of smaller particles. Such a grain size distribution correlates with magnetic grain size estimation (see Table 1), as well as with a previous study of wear particles by Mosleh et al. (2004), who found a bimodal size distribution of $350 \mathrm{~nm}$ and 2-15 $\mu \mathrm{m}$. As can be seen in Fig. 3, there are also larger particle agglomerates $(>15 \mu \mathrm{m})$ that may be produced by wear debris entrapped at a sliding interface. Most debris can be attributed to friction, delamination and fatigue wear (Mosleh et al., 2004). Micron-sized particles with a high content of Fe, Ba, $\mathrm{C}, \mathrm{O}, \mathrm{Al}, \mathrm{Si}$ and $\mathrm{S}$ were found by EDS analysis (Table 2; major elemental contributions for each area are highlighted). It is worth mentioning that $\mathrm{Mg}, \mathrm{Al}, \mathrm{Cu}, \mathrm{Zn}$ and $\mathrm{Cr}$ were detected in 
minor concentrations. These elements are consistent with typical brake materials and wear particles reported in the literature (e.g. Mosleh et al., 2004; Chan and Stachowiak, 2004).

Since road and soil-deposited pollutants are of interest in this study, SEM of magnetic extracts from scraped sediments, swept sediments and soil samples was also carried out. The corresponding micrographs are shown in Figs. 4, 5 and 6.

Fig. 4 shows micrographs obtained from scraped sediment samples from the Samborombon (lower right) and Maipu sites. Large particles with well-defined edges (probably of lithogenic origin), particles of irregular morphology and agglomerates consisting of particles of a variety of shapes and sizes are observed. These agglomerates are formed by irregular particles, flakelike aggregates and rounded (spheroidal) particles of different grain sizes $(\sim 20-10 \mu \mathrm{m}$ and $<10 \mu \mathrm{m})$. EDS results show high concentrations of $\mathrm{C}, \mathrm{O}, \mathrm{Al}, \mathrm{Si}, \mathrm{K}$ and Fe. From Table 2, it is apparent that the particle with well-defined edges (zone 1 in Fig. 4) has a lower concentration of $\mathrm{C}$ and $\mathrm{O}$ and a higher concentration of $\mathrm{Al}, \mathrm{Si}$ and $\mathrm{K}$ than the other particles. The presence of other relevant elements, such as $\mathrm{Na}, \mathrm{Mg}, \mathrm{S}, \mathrm{Ca}, \mathrm{Ti}, \mathrm{Ba}, \mathrm{Mn}, \mathrm{Cu}, \mathrm{Zn}$ and $\mathrm{Cr}$, was also detected.

The SEM and EDS analyses of swept sediments from the Samborombon site (LSB samples) are displayed in Fig. 5 and Table 2. The micrographs show particles of varied grain size, with differing morphologies. Some are large $(\sim 10-30 \mu \mathrm{m}$ and higher $)$ ellipsoidal and pear-like bodies with high Fe, O, C, Ti and Ba contents (e.g. areas p and q in Fig. 5). Large particles with well-defined edges are also Fe-rich (zone $r$ in Fig. 5), but have higher concentrations of $\mathrm{O}$ and Si. Contrastingly, sub-micron and micron-sized particles are observed in the form of spherules and agglomerates of smaller particles. It is possible to observe in one of the enlarged images that large agglomerates with a grain size of $\sim 5 \mu \mathrm{m}$ consist of sub-micron irregular particles and spherulites: most of these are fused and occur at surface level. The second enlarged image allows the identification of spherules of about $4 \mu \mathrm{m}$ (Fig. 5, lower 
right) and smaller agglomerates of irregular particles $(<1-5 \mu \mathrm{m})$ added to larger ones. From EDS analysis, the small spherules are Fe-rich and contain moderate levels of $\mathrm{C}, \mathrm{O}, \mathrm{Ti}, \mathrm{V}, \mathrm{Ba}$ and $\mathrm{Mn}$ (area t in Fig. 5). In contrast, the small agglomerates show a balanced concentration of $\mathrm{C}, \mathrm{O}$ and $\mathrm{Fe}$, as well as the minor presence of $\mathrm{Al}, \mathrm{Si}, \mathrm{Ti}, \mathrm{Ba}$, and $\mathrm{Pb}$ (zone $\mathrm{u}$ in Fig. 5).

Micrographs and elemental compositions of soil samples are shown in Fig. 6 and Table 2. Large micron-sized particles with spheroid-like morphologies (about $100 \mu \mathrm{m}$ ) and aggregates of very small particles are observed. The larger particles contain high levels of $\mathrm{C}, \mathrm{O}$ and Fe, as well as lower amounts of $\mathrm{Al}, \mathrm{Si}, \mathrm{K}, \mathrm{Ca}, \mathrm{Ti}, \mathrm{Ba}, \mathrm{Mn} \mathrm{Cu}$ and $\mathrm{Zn}$ (zones $\mathrm{w}$ and $\mathrm{x}$ in Fig. 6). Other large particles with well-defined edges and a fibre-like shape can be discerned in zones $\mathrm{v}$ and $\mathrm{y}$ (Fig. 6), respectively. The former have higher concentrations of Fe than the spheroidal bodies, but the latter fibre-like particles show the highest concentration of Fe (Table 2; major elemental contributions for each area are highlighted). These are probably brake materialderived wear particles (see Fig. 3 and 6).

In the enlarged images we can observe agglomerates consisting of small irregular particles. Some of these occur as large flake-like bodies (area z in Fig.6) with a high concentration of C, $\mathrm{O}, \mathrm{Al}, \mathrm{Si}$ and $\mathrm{Fe}$ and minor amounts of $\mathrm{Na}, \mathrm{Mg}, \mathrm{K}, \mathrm{Ca}, \mathrm{Ti}, \mathrm{Mn}, \mathrm{Cu}$ and $\mathrm{Zn}$. Most aggregates of sub-micron and micron-sized particles are found attached to large particles. The elemental composition of zone za (Fig. 6) shows a balanced concentration of $\mathrm{C}, \mathrm{O}, \mathrm{Si}$ and Fe, as well as minor levels of other elements (see Table 2; major elemental contributions for each area are highlighted).

\section{Conclusions}

Results of rock-magnetic parameters and their analyses suggest that the magnetic signal of vehicle-derived emissions is controlled by a magnetite-like phase. Although all samples show similar magnetic behaviour, it is possible to differentiate them according to magnetic 
concentration and features-dependent parameters. Concentration-dependent parameters from sediments and soils show a clear trend, with higher values for scraped sediments, intermediate values for swept sediments and lower values for soils. In terms of primary sources, brake samples show the highest values of concentration parameters, with diesel samples the lowest (lower even than sediments and soils). Magnetic grain size estimations are in most samples below $5 \mu \mathrm{m}$, finer $(0.1-1 \mu \mathrm{m})$ for soot samples. This presence of fine particles is significant because they can be inhaled and therefore have adverse human health effects.

Chemical analysis yielded high concentrations of $\mathrm{Ba}, \mathrm{Cr}, \mathrm{Cu}, \mathrm{Zn}$ and $\mathrm{Pb}$ for sediment and soil samples, reaching up to thirteen times baseline values. Such elemental abundance can therefore be interpreted as reflecting an anthropogenic contribution from vehicle-derived emissions. In addition, metal enrichment can also be appreciated from the PLI. Here the highest values belonged to brake samples (up to 15.0), while scraped sample PLI values are higher than those of swept and soil samples.

Observations made by SEM showed small individual particles or spherulites, small aggregates in the form of chains or clusters, large aggregates of spherules, flake-like bodies, fibre-like particles, sheet-like particles, irregular debris and large particle agglomerates (i.e. a wide variety of shapes), with grain sizes in agreement with magnetic estimations. Additionally, nineteen elements were detected by EDS analysis. Among them, C, O, and Fe were the main components followed by $\mathrm{Na}, \mathrm{Mg}, \mathrm{Al}, \mathrm{Si}, \mathrm{S}, \mathrm{K}, \mathrm{Ca}, \mathrm{Ti}, \mathrm{Ba}, \mathrm{Mn}, \mathrm{Zn}, \mathrm{Cr}$ and $\mathrm{Pb}$.

The present study is useful not only for improving our basic knowledge of primary emissions and their magnetic monitoring, but also for the identification of pollution sources and their influence on the human population. PM vehicle-derived emissions comprise a wide variety of metals, toxic elements and also magnetic particles that have an adverse influence on human health. The consequences of these inhalable pollutants include, among others, allergic sensitization, severe tissue damage, pulmonary diseases and cardiovascular toxicity. 


\section{Acknowledgements}

The authors would like to thank the CONICET, UNCPBA and UNMdP. Financial support was also received from a PICT-2005 of the ANPCYT, project No. 38050 and by the CICYT project MEDEROCAR (CGL2008-0831). The authorities (Ing. M. Vincent) and staff of tollbooth Autovia 2 (Samborombon and Maipu) are thanked for their useful help in carrying out the sampling. We are also grateful to Mr. Lucas Conde (IFAS) for his help during the Samborombon campaign. Finally the authors thank the anonymous reviewer and Dr. S Bijaksana for their constructive comments and suggestions. 


\section{References}

Abdul-Razzaq W, Gautam M (2001) Discovery of magnetite in the exhausted material from a diesel engine. App Phys Lett, 78: 2018-2019

Amereih S, Meisel T, Scholger R, Wegscheider W (2005) Antimony speciation in soil samples along two Austrian motorways by HPLC-ID-ICP-MS, J. Environ. Monit, 7, 1200-1206.

Berube KA, Jones TP, Winters C, Morgan AJ, Richards RJ (1999) Physicochemical characterisation of diesel exhaust particles: Factor for assessing biological activity. Atm. Environ., 33:1599-1614.

Chan D, Stachowiak GW (2004) Review of automotive brake friction materials. Proc. Instn Mech. Engrs., 218(Part D: J Automobile Engineering):953-966.

Chaparro MAE, Bidegain JC, Sinito AM, Gogorza CSG, Jurado S, (2004) Magnetic studies applied to different environments (soils and stream-sediments) from a relatively polluted area in Buenos Aires Province, Argentina. Environ. Geol., 45:654-664.

Flanders PJ (1994) Collection, measurement, and analysis of airborne magnetic particulates from pollution in the environment. J. Appl. Phys,, 75(10):5931-5936

Geller MD, Ntziachristos L, Mamakos A, Samaras Z, Schmitz DA, Froines JR, Sioutas C (2006) Physicochemical and redox characteristics of particulate matter (PM) emitted from gasoline and diesel passenger cars. Atm. Environ., 40:6988-7004.

Hilger I, Fruhauf S, Linss W, Hiergeist R, Andra W, Hergt R, Kaiser W (2003) Cytotoxicity of selected magnetic fluids on human adenocarcinoma cells. J Magnetism Magnetic Materials, 261:7-12

Huhn G, Schulz H, Staerk HJ, Toelle R, Scheuermann G (1995) Evaluation of regional heavy metal deposition by multivariate analysis of element contents in pine tree barks. Water Air Soil Pollut., 84:367-383.

Kasper M, Sattler K, Siegmann K, Matter U, Siegmann HC (1999) The influence of fuel additives on the formation of carbon during combustion. J. Aerosol Sci., 30(2):217-225

Kim W, Doh S-J, Park Y-H, Yun S-T (2007) Two-year magnetic monitoring in conjunction with geochemical and electron microscopic data of roadside dust in Seoul, Korea. Atm. Environ., 41: 7627-7641 
Knox E.G. (2006) Roads, railways and childhood cancers. Journal of Epidemiology and Community Health 60, 136-141.

Knutsen S., Shavlik D., Chen L.H., BeesonW.L., Ghamsary M., Petersen F. (2004) The association between ambient particulate air pollution levels and risk of cardiopulmonary and all-cause mortality during 22 years follow-up of a non-smoking cohort. Results from the AHSMOG study. Epidemiology 15, S45.

Kirschvink JL, Kobayashi-Kirschvink A, Woodford BJ (1992). Magnetite biomineralization in the human brain. Proc. Natl. Acad. Sci. USA 89:7683

Lavado R.S., Zubillaga M.S., Alvarez R. and Taboada M.A. (2004) Baseline levels of potentially 7 toxic elements in Pampas soils. Soil. Sediment. Contam., 13, 427-437

Lim M.C.H., Ayodo G.A., Morawska L., Ristovski Z.D. and Jayaratne E.R. (2007) The effects of fuel characteristics and engine operating conditions on the elemental composition of emissions from duty diesel buses. Fuel, 86, 1831-1839.

Lin C.-C., Chen S.-J. and Huang K.L. (2005) Characteristics of metals in nano/ultrafine/fine/coarse particles collected beside a heavily trafficked road. Environ. Sci. Technol., 39, 8113-8122..

Lu S-G, Bai S-Q, Cai J-B, Xu C (2005) Magnetic properties and heavy metal contents of automobile emission particulates. J. Zhejiang Univ. SCI., 6B(8): 731-735.

Maher BA, Moore C, Matzka J (2008) Spatial variation in vehicle-derived metal pollution identified by magnetic and elemental analysis of roadside tree leaves. Atm. Environ., 42, 364-373.

Marié D.C., Chaparro M.A.E., Gogorza C.S.G., Navas A., Sinito A.M. (2010) Vehicle-derived emissions and pollution on the road Autovia 2 investigated by rock-magnetic parameters: a case of study from Argentina, Studia Geophysica et Geodaetica,54(1): 135-152.

Mosleh M, Blau PJ, Dumitrescu D (2004) Characteristics and morphology of wear particles from laboratory testing of disk brake materials. Wear, 256:1128-1134.

Navas A, Machín J (2002) Spatial distribution of heavy metals and arsenic in soils of Aragón (NE Spain): controlling factors and environmental implications. App. Geochem., 17: 961-973.

Palmgren F., Waahlin P., Kildesó J., Afshari A., Fogh C.L. (2003) Characterisation of particle emissions from the driving car fleet and the contribution to ambient and indoor particle concentrations, Phys. Chem. Earth, $28,327-334$ 
Peters C, Dekkers MJ (2003) Selected room temperature magnetic parameters as a function of mineralogy, concentration and grain size. Phys. Chem. Earth, 28: 659-667.

Pope C.A., Burnett R.T., Thun M.J., Calle E.E., Krewski D., Kazuhiko I., Thurston G.D. (2002) Lung cancer, cardiopulmonary mortality, and long-term exposure to fine particulate air pollution. J American Medical Association 287, 1132-1141.

Pope C.A., Dockery D.W. (2006) Health effects of fine particulate air pollution: lines that connect. J Air Waste Manage Assoc 56:709-742

Rizzio E, Giaveri G, Arginelli D, Gini L, Profumo A, Gallorini M (1999) Trace elements total content and particle sizes distribution in the air particulate matter of rural-residential area in the north Italy investigated by instrumental neutron activation analysis. Sci. Tot. Environ., 226: 47-56.

Tomlinson, D.L., Wilson, J.G., Harris, C.R. and Jeffrey, D.W. (1980) Problems in the assessment of heavy metals levels in estuaries and the formation of a pollution index. Helgol. Meeresunters, 33: 566-575.

Vouitsis E, Ntziachristos L, Pistikopoulos P, Samaras Z, Chrysikou L, Samara C, Papadimitriou C, Samaras P, Sakellaropoulos G (2009) An investigation on the physical, chemical and ecotoxicological characteristics of particulate matter emitted from light-duty vehicles. Environ Poll., 157:2320-2327.

Wang Y.-F., Huang K.-L., Li C.-T., Mi H.-H., Luo J.-H. and Tsai P.-J. (2003) Emissions of fuel metals content from a diesel vehicle engine. Atmos. Environ. 37, 4637-4643.

Weckwerth G. (2001) Verification of traffic emitted aerosol components in the ambient air of Cologne (Germany). Atmos. Environ., 35, 5525-5536.

Yao Q, Li S-Q, Xu H-W, Zhuo J-K, Song Q (2009) Studies on formation and control of combustion particulate matter in China: A review. Energy, 34:1296-1309.

Zhang C, Huang B, Li Z, Liu, H (2006) Magnetic properties of highroad-side pine tree leaves in Beijing and their environmental significance. Chinese Sci. Bull., 51(24):3041-3052 


\section{Figure and table captions}

Table 1. Magnetic properties, elemental composition and the PLI (Tomlinson index) of material from primary sources (diesel/gas soot, wear particles from brake materials), sediments and soil samples.

Table 2. EDS results for magnetic extracts. The letters a-zb correspond to different areas and zones studied on the micrographs (see Fig. 1-6). The highest concentrations of five elements for each area/zone (column) are shown in bold type.

Fig. 1. Diesel samples (magnetic extracts) observed by SEM. Additional trace element information was obtained by EDS analysis. EDS analysis of different areas is shown (a and b). The lower micrographs are enlarged views.

Fig. 2. Gas samples (magnetic extracts) observed by SEM. Additional trace element information was obtained by EDS analysis of different zones and areas (c, $d$ and e). The micrograph on the lower right is an enlarged view.

Fig. 3. Brake samples (magnetic extracts) observed by SEM. Additional trace element information was obtained by EDS analysis. The micrograph on the lower left is an enlarged view. The EDS analysis of different areas and zones are shown (f, g, h, i, j and k).

Fig. 4. Scraped sediments samples (magnetic extracts) observed by SEM. Additional trace element information (for areas and zones $1, \mathrm{~m}, \mathrm{n}$ and $\mathrm{o}$ ) was obtained by EDS analysis.

Fig. 5. Swept sediments samples (magnetic extract) observed by SEM. Additional trace element information s was obtained by EDS analysis for areas and zones $\mathrm{p}, \mathrm{q}, \mathrm{r}, \mathrm{s}, \mathrm{t}$ and $\mathrm{u}$. The lower micrographs are enlarged views.

Fig. 6. Soil samples (magnetic extract) observed by SEM. Additional trace element information was obtained by EDS analysis of areas and zones $\mathrm{v}, \mathrm{w}, \mathrm{x}, \mathrm{y}, \mathrm{z}, \mathrm{za}$ and $\mathrm{zb}$. The micrograph on the lower right is an enlarged view. 


\begin{tabular}{|c|c|c|c|c|c|c|c|c|c|c|c|c|c|c|c|c|}
\hline \multirow[t]{2}{*}{ Variable } & \multicolumn{4}{|c|}{ Primary Sources(vehicles) } & & \multicolumn{4}{|c|}{ Scraped sediments } & \multicolumn{2}{|c|}{$\begin{array}{l}\text { Swept sediments } \\
\text { LM }\end{array}$} & & \multicolumn{2}{|l|}{ Soils } \\
\hline & $n$ & $\begin{array}{l}\text { Diesel } \\
\text { mean (sd) } \\
{[\text { min; max] }}\end{array}$ & $n$ & $\begin{array}{l}\text { Gas } \\
\text { mean (sd) } \\
\text { [min; max] }\end{array}$ & $n$ & $\begin{array}{l}\text { Brake } \\
\text { mean (sd) } \\
{[\text { min; max] }}\end{array}$ & $n$ & $\begin{array}{l}\mathrm{SM}-\mathrm{CM} \\
\text { mean (sd) } \\
{[\text { min; max] }}\end{array}$ & $n$ & $\begin{array}{l}\text { RSB } \\
\text { mean (sd) } \\
\text { [min; max] }\end{array}$ & $n$ & $\begin{array}{l}\text { LM } \\
\text { mean (sd) } \\
\text { [min; max] }\end{array}$ & $n$ & $\begin{array}{l}\text { LSB } \\
\text { mean (sd) } \\
{[\text { min; max] }}\end{array}$ & $n$ & $\begin{array}{l}\text { MP } \\
\text { mean (sd) } \\
{[\text { min; max] }}\end{array}$ \\
\hline$\chi[10-8 \mathrm{~m} 3 \mathrm{~kg}-1]$ & 11 & $\begin{array}{l}298.3(307.5) \\
{[2.4 ; 903.6]}\end{array}$ & 7 & $\begin{array}{l}1107(763.3) \\
{[402.1 ; 2486]}\end{array}$ & 4 & $\begin{array}{l}15819(10360) \\
{[5826 ; 26601]}\end{array}$ & 24 & $\begin{array}{l}502.8(153.4) \\
{[302.9 ; 1037.0]}\end{array}$ & 12 & $\begin{array}{l}415.3(104.5) \\
{[186.3 ; 571.9]}\end{array}$ & 10 & $\begin{array}{l}324.2(71.8) \\
{[221.4 ; 484.1]}\end{array}$ & 14 & $\begin{array}{l}364.6(74.5) \\
{[127.4 ; 462.4]}\end{array}$ & 10 & $\begin{array}{l}234.0(69.4) \\
{[130.7 ; 338.8]}\end{array}$ \\
\hline ARM [10-6 A m2 kg-1] & 11 & $\begin{array}{l}358.5(297.4) \\
{[18.2 ; 907.5]}\end{array}$ & 7 & $\begin{array}{l}1606(736.3) \\
{[834.9 ; 3078]}\end{array}$ & 4 & $\begin{array}{l}13783(4732) \\
{[8197 ; 18594]}\end{array}$ & 24 & $\begin{array}{l}620.7(101.7) \\
{[435.0 ; 926.7]}\end{array}$ & 12 & $\begin{array}{l}584.6(85.3) \\
{[442.3 ; 702.4]}\end{array}$ & 10 & $\begin{array}{l}414.8(136.4) \\
{[273.0 ; 745.7]}\end{array}$ & 14 & $\begin{array}{l}569.6(60.1) \\
{[479.6 ; 693.4]}\end{array}$ & 10 & $\begin{array}{l}495.4(100.9) \\
{[345.7 ; 693.6]}\end{array}$ \\
\hline SIRM [10-3 A m2 kg-1] & 11 & $\begin{array}{l}26.2(26.8) \\
{[1.2 ; 73.6]}\end{array}$ & 7 & $\begin{array}{l}134.9(80.0) \\
{[41.3 ; 269.1]}\end{array}$ & 4 & $\begin{array}{l}884.6(356.1) \\
{[569.6 ; 1201]}\end{array}$ & 24 & $\begin{array}{l}48.3(14.9) \\
{[33.2 ; 111.5]}\end{array}$ & 12 & $\begin{array}{l}41.2(17.0) \\
{[16.3 ; 71.7]}\end{array}$ & 10 & $\begin{array}{l}39.3(11.7) \\
{[24.3 ; 64.8]}\end{array}$ & 14 & $\begin{array}{l}46.3(9.7) \\
{[16.3 ; 54.7]}\end{array}$ & 10 & $\begin{array}{l}27.5(7.7) \\
{[15.4 ; 42.9]}\end{array}$ \\
\hline $\mathrm{Hcr}[\mathrm{mT}]$ & 11 & $\begin{array}{l}33.1(8.6) \\
{[23.1 ; 55.0]}\end{array}$ & 7 & $\begin{array}{l}31.0(5.4) \\
{[21.6 ; 36.4]}\end{array}$ & 4 & $\begin{array}{l}17.4(14.0) \\
{[6.1 ; 35.5]}\end{array}$ & 24 & $\begin{array}{l}36.0(2.1) \\
{[31.9 ; 39.1]}\end{array}$ & 12 & $\begin{array}{l}36.2(2.0) \\
{[32.9 ; 39.3]}\end{array}$ & 10 & $\begin{array}{l}34.4(2.2) \\
{[31.7 ; 39.8]}\end{array}$ & 14 & $\begin{array}{l}34.0(1.0) \\
{[32.4 ; 36.7]}\end{array}$ & 10 & $\begin{array}{l}35.2(2.5) \\
{[32.3 ; 38.7]}\end{array}$ \\
\hline S-ratio [dimensionless] & 11 & {$[0.91 ; 1.00]$} & 7 & {$[0.96 ; 1.00]$} & 4 & {$[0.96 ; 1.00]$} & 24 & {$[0.92 ; 0.98]$} & 12 & {$[0.90 ; 0.97]$} & 10 & {$[0.93 ; 0.98]$} & 14 & {$[0.90 ; 0.97]$} & 10 & {$[0.92 ; 0.97]$} \\
\hline $\mathrm{SIRM} / \kappa[\mathrm{kA} / \mathrm{m}]$ & 11 & $\begin{array}{l}14.5(12.1) \\
{[3.9 ; 47.4]}\end{array}$ & 7 & $\begin{array}{l}13.8(6.3) \\
{[7.3 ; 23.2]}\end{array}$ & 4 & $\begin{array}{l}6.7(2.5) \\
{[4.5 ; 10.0]}\end{array}$ & 24 & $\begin{array}{l}9.7(0.9) \\
{[7.7 ; 12.6]}\end{array}$ & 12 & $\begin{array}{l}9.9(3.0) \\
{[4.0 ; 14.5]}\end{array}$ & 10 & $\begin{array}{l}12.0(1.2) \\
{[10.0 ; 14.4]}\end{array}$ & 14 & $\begin{array}{l}12.7(1.1) \\
{[10.9 ; 14.5]}\end{array}$ & 10 & $\begin{array}{l}12.1(3.0) \\
{[8.1 ; 18.6]}\end{array}$ \\
\hline$\kappa_{\text {ARM }} / \kappa$ [dimensionless] & 11 & $\begin{array}{l}3.4(2.4) \\
{[0.4 ; 9.0]}\end{array}$ & 7 & $\begin{array}{l}2.7(1.2) \\
{[1.1 ; 3.9]}\end{array}$ & 4 & $\begin{array}{l}1.5(0.8) \\
{[1.0 ; 2.7]}\end{array}$ & 24 & $\begin{array}{l}1.7(0.3) \\
{[1.0 ; 2.1]}\end{array}$ & 12 & $\begin{array}{l}1.6(0.3) \\
{[1.1 ; 2.4]}\end{array}$ & 10 & $\begin{array}{l}1.7(0.3) \\
{[1.2 ; 2.3]}\end{array}$ & 14 & $\begin{array}{l}2.5(1.7) \\
{[1.7 ; 8.3]}\end{array}$ & 10 & $\begin{array}{l}3.1(1.0) \\
{[1.6 ; 4.2]}\end{array}$ \\
\hline mag. Grain size* $[\mu \mathrm{m}]$ & 11 & {$[0.1 ; 5]$} & 7 & {$[0.2 ; 5]$} & 4 & {$[1 ; 5]$} & 24 & {$[1 ; 5]$} & 12 & {$[1 ; 5]$} & 10 & {$[1 ; 5]$} & 14 & {$[1 ; 5]$} & 10 & {$[0.2 ; 1]$} \\
\hline $\mathrm{Ba}[\mathrm{mg} / \mathrm{kg}]$ & -- & -- & -- & -- & 2 & $\begin{array}{l}231.0(163.2) \\
{[115.5 ; 346.4]}\end{array}$ & 7 & $\begin{array}{l}366.8(41.2) \\
{[309.4 ; 423.1]}\end{array}$ & 3 & $\begin{array}{l}389.9(9.3) \\
{[379.1 ; 395.3]}\end{array}$ & 5 & $\begin{array}{l}434.9(205.6) \\
{[279.5 ; 793.8]}\end{array}$ & 5 & $\begin{array}{l}350.6(18.6) \\
{[325.5 ; 376.4]}\end{array}$ & 10 & $\begin{array}{l}411.2(131.6) \\
{[251.6 ; 595.3]}\end{array}$ \\
\hline $\mathrm{Cr}[\mathrm{mg} / \mathrm{kg}]$ & -- & -- & -- & -- & 2 & $\begin{array}{l}268.5(69.5) \\
{[219.3 ; 317.6]}\end{array}$ & 7 & $\begin{array}{l}52.8(4.5) \\
{[45.0 ; 58.5]}\end{array}$ & 3 & $\begin{array}{l}50.2(11.6) \\
{[38.8 ; 61.9]}\end{array}$ & 5 & $\begin{array}{l}42.0(7.8) \\
{[33.4 ; 54.0]}\end{array}$ & 5 & $\begin{array}{l}48.2(6.3) \\
{[43.1 ; 57.7]}\end{array}$ & 10 & $\begin{array}{l}38.0(5.4) \\
{[27.7 ; 46.9]}\end{array}$ \\
\hline $\mathrm{Cu}[\mathrm{mg} / \mathrm{kg}]$ & -- & -- & -- & -- & 2 & $\begin{array}{l}15541(20466) \\
{[1070 ; 30013]}\end{array}$ & 7 & $\begin{array}{l}116.2(35.2) \\
{[76.7 ; 186.2]}\end{array}$ & 3 & $\begin{array}{l}143.3(61.8) \\
{[87.0 ; 209.4]}\end{array}$ & 5 & $\begin{array}{l}129.4(126.3) \\
{[24.2 ; 333.8]}\end{array}$ & 5 & $\begin{array}{l}138.4(56.3) \\
{[50.9 ; 195.6]}\end{array}$ & 10 & $\begin{array}{l}29.2(7.3) \\
{[17.8 ; 42.2]}\end{array}$ \\
\hline Zn [mg/kg] & -- & -- & -- & -- & 2 & $\begin{array}{l}6962(3527) \\
{[4468 ; 9457]}\end{array}$ & 7 & $\begin{array}{l}303.9(48.8) \\
{[244.9 ; 392.9]}\end{array}$ & 3 & $\begin{array}{l}348.9(93.9) \\
{[244.0 ; 425.3]}\end{array}$ & 5 & $\begin{array}{l}157.0(85.9) \\
{[82.0 ; 295.7]}\end{array}$ & 5 & $\begin{array}{l}191.3(20.5) \\
{[159.7 ; 214}\end{array}$ & 10 & $\begin{array}{l}155.5(34.1) \\
{[118.5 ; 221.6]}\end{array}$ \\
\hline Co $[\mathrm{mg} / \mathrm{kg}]$ & -- & -- & -- & -- & 2 & $\begin{array}{l}8.0(3.7) \\
{[5.4 ; 10.6]}\end{array}$ & 7 & $\begin{array}{l}7.8(1.1) \\
{[6.0 ; 9.2]}\end{array}$ & 3 & $\begin{array}{l}7.3(1.1) \\
{[6.2 ; 8.4]}\end{array}$ & 5 & $\begin{array}{l}4.5(1.2) \\
{[2.9 ; 5.7]}\end{array}$ & 5 & $\begin{array}{l}8.7(2.7) \\
{[6.5 ; 12.9]}\end{array}$ & 10 & $\begin{array}{l}8.9(1.1) \\
{[6.9 ; 10.2]}\end{array}$ \\
\hline $\mathrm{Cd}[\mathrm{mg} / \mathrm{kg}]$ & -- & -- & -- & -- & 2 & $\begin{array}{l}10.6(5.0) \\
{[7.0 ; 14.1]}\end{array}$ & 7 & $\begin{array}{l}1.3(0.4) \\
{[0.9 ; 1.9]}\end{array}$ & 2 & $\begin{array}{l}0.2(0.0) \\
{[0.1 ; 0.2]}\end{array}$ & 5 & $\begin{array}{l}0.8(0.2) \\
{[0.6 ; 1.1]}\end{array}$ & 1 & $\begin{array}{l}0.0(0.0) \\
{[0.0]}\end{array}$ & 4 & $\begin{array}{l}0.2(0.2) \\
{[0.1 ; 0.5]}\end{array}$ \\
\hline $\mathrm{Pb}[\mathrm{mg} / \mathrm{kg}]$ & -- & -- & -- & -- & 2 & $\begin{array}{l}184.3(136.5) \\
{[87.8 ; 280.7]}\end{array}$ & 7 & $\begin{array}{l}124.1(15.2) \\
{[106.0 ; 153.0]}\end{array}$ & 3 & $\begin{array}{l}132.5(32.7) \\
{[98.0 ; 163.2]}\end{array}$ & 5 & $\begin{array}{l}92.5(36.8) \\
{[56.2 ; 150.3]}\end{array}$ & 5 & $\begin{array}{l}129.1(43.5) \\
{[100.8 ; 205.9]}\end{array}$ & 10 & $\begin{array}{l}246.1(103.8) \\
{[154.8 ; 461.1]}\end{array}$ \\
\hline PLI** [dimensionless] & -- & -- & -- & -- & & {$[11.6 ; 14.9]$} & 7 & {$[2.7 ; 3.3]$} & & {$[2.8 ; 4.3]$} & & {$[1.4 ; 2.9]$} & & {$[2.8 ; 3.6]$} & & {$[1.9 ; 3.1]$} \\
\hline
\end{tabular}

*estimated from King's plot; **the PLI was calculated using 6 toxic elements (Ba, Cr, Cu, $\mathrm{Zn}$, Co and Pb), their corresponding baseline values (in mg/kg) are: $110.0 ; 11.1 ; 12.8 ; 44.5 ; 34.8$ and 18.7 



\section{Table 2}

\begin{tabular}{|c|c|c|c|c|c|c|c|c|c|c|c|c|c|c|c|c|c|c|c|c|c|c|c|c|c|c|c|c|}
\hline \multirow[t]{4}{*}{ Element } & \multicolumn{11}{|c|}{ Primary sources (vehicles) } & \multicolumn{4}{|c|}{ Scraped sediments } & \multicolumn{6}{|c|}{ Swept sediments } & \multicolumn{7}{|l|}{ Soils } \\
\hline & \multicolumn{4}{|c|}{ Diesel $\quad$ Gas } & \multicolumn{3}{|c|}{ Brake } & \multirow{3}{*}{$\begin{array}{c}\mathrm{h} \\
{[\mathrm{wt} \%]}\end{array}$} & \multirow{3}{*}{$\begin{array}{c}\mathrm{i} \\
{[\mathrm{Wt} \%]}\end{array}$} & \multirow{3}{*}{$\begin{array}{c}\mathrm{j} \\
{[\mathrm{Wt} \%]}\end{array}$} & \multirow{3}{*}{$\begin{array}{c}\mathrm{k} \\
{[\mathrm{Wt} \%]}\end{array}$} & \multirow{3}{*}{$\begin{array}{c}\text { I } \\
{[\mathrm{Wt} \%]}\end{array}$} & \multirow{3}{*}{$\begin{array}{c}\mathrm{m} \\
{[\mathrm{Wt} \%]}\end{array}$} & \multirow{3}{*}{$\begin{array}{c}n \\
{[\mathrm{Wt} \%]}\end{array}$} & \multirow{3}{*}{$\begin{array}{c}\circ \\
{[\mathrm{Wt} \%]}\end{array}$} & & \multirow[b]{2}{*}{$q$} & \multirow{2}{*}{$r$} & \multirow[b]{2}{*}{$\mathrm{s}$} & \multirow[b]{2}{*}{$\mathrm{t}$} & \multirow{2}{*}{$\mathrm{u}$} & & & & & & & \\
\hline & $\mathrm{a}$ & b & c & $\mathrm{d}$ & e & f & $\mathrm{g}$ & & & & & & & & & & & & & & & $\mathrm{v}$ & w & $\mathrm{x}$ & $y$ & $z$ & za & $\mathrm{zb}$ \\
\hline & [Wt \%] & {$[\mathrm{Wt} \%]$} & {$[\mathrm{Wt} \%]$} & {$[\mathrm{Wt} \%]$} & {$[W t \%]$} & [Wt \%] & {$[\mathrm{Wt} \%]$} & & & & & & & & & {$[\mathrm{Wt} \%]$} & {$[\mathrm{Wt} \%]$} & {$[\mathrm{Wt} \%]$} & {$[\mathrm{Wt} \%]$} & {$[\mathrm{Wt} \%]$} & {$[\mathrm{Wt} \%]$} & {$[\mathrm{Wt} \%]$} & {$[\mathrm{Wt} \%]$} & {$[\mathrm{Wt} \%]$} & {$[\mathrm{Wt} \%]$} & {$[\mathrm{Wt} \%]$} & {$[\mathrm{Wt} \%]$} & {$[\mathrm{Wt} \%]$} \\
\hline C & 85.58 & 80.78 & 63.78 & 53.99 & 68.48 & 16.32 & 39.09 & 24.27 & 21.32 & 19.01 & 18.96 & 7.88 & 37.58 & 54.59 & 56.89 & 9.93 & 4.51 & 6.33 & 5.10 & 2.38 & 15.84 & 15.64 & 26.52 & 11.76 & 9.06 & 33.55 & 22.19 & 5.81 \\
\hline 0 & 3.94 & 3.03 & 17.14 & 13.54 & 9.83 & 14.18 & 8.95 & 17.85 & 20.46 & 3.96 & 28.03 & 2.20 & 18.22 & 14.09 & 22.00 & 18.71 & 6.90 & 30.80 & 3.55 & 0.67 & 17.15 & 4.51 & 16.40 & 25.51 & 3.56 & 15.18 & 16.09 & 24.37 \\
\hline $\mathrm{Na}$ & 0.04 & 0.07 & 0.26 & 2.21 & 1.55 & 0.34 & 0.07 & 0.28 & 0.34 & 0.22 & 0.59 & 0.23 & 0.11 & 0.76 & 0.30 & 0.28 & 0.17 & 0.00 & 0.19 & 0.08 & 0.60 & 0.17 & 0.29 & 0.25 & 0.14 & 0.43 & 0.19 & 0.07 \\
\hline Mg & 0.00 & 0.40 & 0.13 & 1.40 & 0.95 & 3.42 & 0.24 & 0.89 & 3.36 & 0.92 & 1.00 & 0.38 & 0.91 & 0.56 & 0.46 & 0.69 & 0.32 & 2.28 & 0.23 & 0.05 & 0.71 & 0.15 & 0.62 & 1.51 & 0.11 & 0.24 & 0.74 & 0.82 \\
\hline Al & 0.03 & 0.40 & 0.67 & 0.87 & 0.25 & 2.12 & 2.57 & 1.46 & 1.69 & 2.00 & 6.26 & 8.30 & 4.37 & 3.84 & 3.11 & 1.97 & 0.93 & 1.71 & 0.80 & 0.29 & 2.30 & 0.69 & 3.16 & 2.80 & 0.21 & 2.01 & 4.64 & 1.11 \\
\hline $\mathrm{Si}$ & 0.09 & 0.14 & 1.65 & 0.73 & 0.31 & 4.43 & 3.05 & 2.89 & 5.26 & 4.39 & 18.64 & 26.75 & 13.51 & 12.12 & 8.99 & 2.14 & 1.66 & 3.05 & 1.17 & 0.22 & 4.36 & 1.47 & 8.90 & 4.10 & 0.63 & 5.40 & 11.31 & 2.76 \\
\hline $\mathrm{Pd}^{*}$ & 1.66 & 1.74 & 0.91 & 1.45 & 1.78 & 2.21 & 1.32 & 1.00 & 1.79 & 1.00 & 2.71 & 5.85 & 3.35 & 2.61 & 1.47 & 2.10 & 1.13 & 1.17 & 0.24 & 0.11 & 0.72 & 2.26 & 2.61 & 2.38 & 2.35 & 1.68 & 1.95 & 2.30 \\
\hline$P$ & 0.05 & 0.13 & 0.27 & 1.46 & 3.12 & 0.09 & 0.02 & 0.03 & 0.00 & 0.09 & 0.06 & 0.00 & 0.00 & 0.04 & 0.00 & 0.00 & 0.00 & 0.00 & 0.00 & 0.00 & 0.00 & 0.07 & 0.11 & 0.08 & 0.09 & 0.07 & 0.08 & 0.20 \\
\hline S & 0.40 & 0.48 & 3.81 & 1.22 & 1.48 & 6.65 & 7.36 & 7.88 & 1.81 & 2.16 & 0.10 & 0.22 & 0.28 & 0.07 & 0.11 & 0.00 & 0.00 & 0.00 & 0.00 & 0.00 & 0.00 & 0.00 & 0.07 & 0.06 & 1.30 & 0.06 & .15 & 0.08 \\
\hline $\mathrm{K}$ & 0 & 0.04 & 0.08 & 0.00 & 0.00 & 0.95 & 0.46 & 0.18 & 1.28 & 0.78 & 1.24 & 13.56 & 1.69 & 0.74 & 0.81 & 0.15 & 0.42 & 0.00 & 0.13 & 0.08 & 0.50 & 0.11 & 1.32 & 0.22 & 0.09 & 0.50 & 0.87 & 0.11 \\
\hline $\mathrm{Ca}$ & 7 & 0.13 & 3.50 & 0.84 & 3.81 & 0.26 & 0.00 & 0.69 & 0.96 & 1.72 & 2.41 & 0.00 & 1.50 & 1.42 & 0.67 & 0.54 & 0.32 & 0.06 & 0.50 & 0.22 & 0.97 & 0.16 & 1.87 & 0.32 & 0.08 & 1.47 & 1.80 & 0.12 \\
\hline T: & 04 & 0.08 & 0.04 & 0.00 & 0.00 & 0.00 & 0.00 & 0.00 & 0.00 & 0.00 & 0.55 & 0.22 & 0.45 & 25 & 0.11 & 7.91 & 20.23 & 0.16 & 4.05 & 5.91 & 2.36 & 0.11 & 1.56 & 5.17 & 0.14 & 0.76 & 0.48 & 15.72 \\
\hline V & Do & 0.00 & 0.00 & 0.00 & 0.00 & 0.00 & 0.00 & 0.00 & 0.00 & 0.00 & 0.00 & 0.00 & 0.00 & 0.00 & 0.00 & 0.39 & 0.07 & 0.05 & 0.70 & 0.85 & 0.48 & 0.00 & 0.30 & 0.33 & 0.00 & 0.00 & 0.00 & 0.21 \\
\hline $\mathrm{Ba}$ & 0.00 & 0.00 & 0.00 & 0.00 & 0.00 & 9.82 & 6.93 & 31.81 & 1.88 & 7.44 & 0.00 & 0.51 & 0.15 & 0.00 & 0.00 & 0.00 & 6.31 & 0.00 & 0.74 & 2.21 & 1.94 & 0.00 & 1.04 & 0.00 & 0.00 & 0.00 & 0.00 & 0.00 \\
\hline $\mathrm{Mn}$ & 0. & 0.16 & 0.05 & 0.22 & 0.00 & 0.47 & 0.26 & 0.00 & 0.29 & 0.47 & 0.25 & 0.38 & 0.19 & 0.12 & 0.04 & 0.76 & 1.06 & 0.00 & 0.55 & 0.47 & 0.04 & 0.32 & 0.00 & 0.17 & 1.06 & 0.21 & 0.19 & 0.82 \\
\hline $\mathrm{Fe}$ & 0.40 & 0.85 & 0.50 & 9.29 & 1.21 & 21.46 & 16.88 & 3.41 & 23.45 & 51.43 & 8.87 & 1.95 & 4.85 & 1.62 & 1.22 & 40.85 & 48.58 & 44.75 & 67.77 & 81.04 & 32.59 & 59.34 & 15.63 & 32.96 & 68.16 & 14.04 & 28.06 & 35.95 \\
\hline $\mathrm{Cu}$ & 0.12 & 0.29 & 0.11 & 0.47 & 0.00 & 4.09 & 4.43 & 0.45 & 0.98 & 0.57 & 0.33 & 0.34 & 0.48 & 0.23 & 0.08 & 0.27 & 0.16 & 0.39 & 0.00 & 0.00 & 0.00 & 0.52 & 0.14 & 0.12 & 0.43 & 0.53 & 0.16 & 0.33 \\
\hline Zn & 15 & 0.34 & 0.30 & 4.33 & 1.36 & 1.73 & 0.21 & 0.51 & 1.96 & 0.18 & 0.00 & 0.52 & 0.77 & 0.33 & 0.12 & 0.62 & 0.40 & 0.45 & 0.37 & 0.00 & 0.00 & 0.75 & 0.19 & 0.44 & 0.48 & 0.32 & 0.69 & 0.42 \\
\hline SD & Do & 0.00 & 0.00 & 0.00 & 0.00 & 0.00 & 0.00 & 0.00 & 0.00 & 0.00 & 0.00 & 0.00 & 0.00 & 0.00 & 0.00 & 0.00 & 0.00 & 0.00 & 0.00 & 0.00 & 0.00 & 0.00 & 0.00 & 0.00 & 0.00 & 0.00 & 0.00 & 0.00 \\
\hline $\mathrm{Cr}$ & 0.06 & 0.10 & 0.02 & 0.16 & 0.00 & 0.00 & 0.00 & 0.00 & 0.00 & 1.20 & 0.16 & 0.95 & 0.00 & 0.09 & 0.00 & 0.15 & 0.72 & 0.27 & 0.10 & 0.15 & 0.13 & 0.23 & 0.00 & 0.07 & 0.26 & 0.00 & 0.10 & 0.12 \\
\hline $\mathrm{Au}^{*}$ & 7.33 & 11.56 & 6.78 & 7.82 & 5.87 & 11.46 & 8.11 & 6.41 & 13.16 & 2.46 & 9.83 & 29.76 & 11.60 & 6.50 & 3.62 & 12.55 & 6.09 & 8.53 & 13.82 & 5.26 & 16.47 & 13.50 & 19.28 & 11.75 & 11.85 & 23.53 & 10.31 & 8.69 \\
\hline $\mathrm{Pb}$ & 0.00 & 0.00 & 0.00 & 0.00 & 0.00 & 0.00 & 0.00 & 0.00 & 0.00 & 0.00 & 0.00 & 0.00 & 0.00 & 0.00 & 0.00 & 0.00 & 0.00 & 0.00 & 0.00 & 0.00 & 2.81 & 0.00 & 0.00 & 0.00 & 0.00 & 0.00 & 0.00 & 0.00 \\
\hline
\end{tabular}

* For the specimen preparation, a Au/Pd coating was deposited 


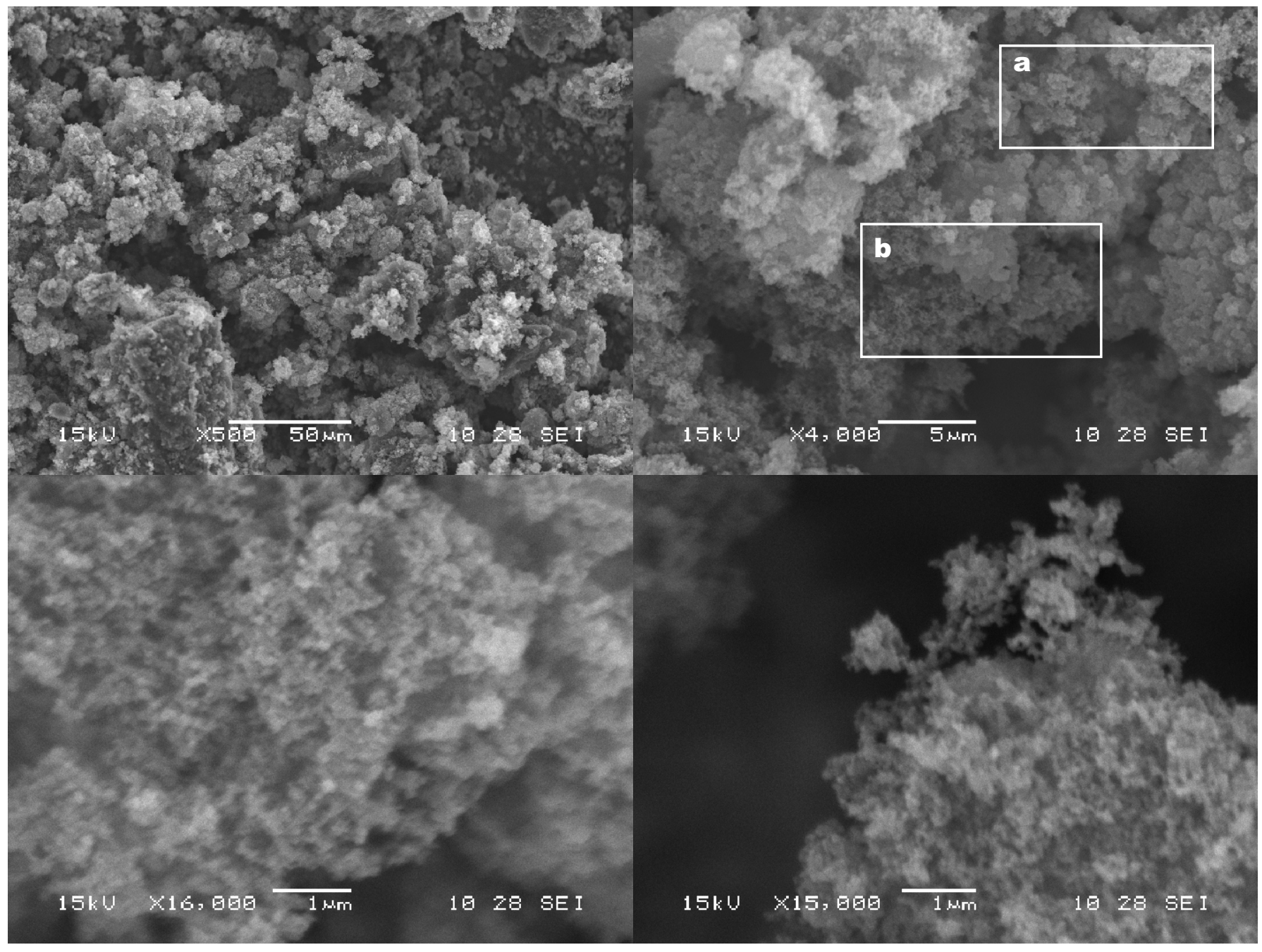

Fig. 1 


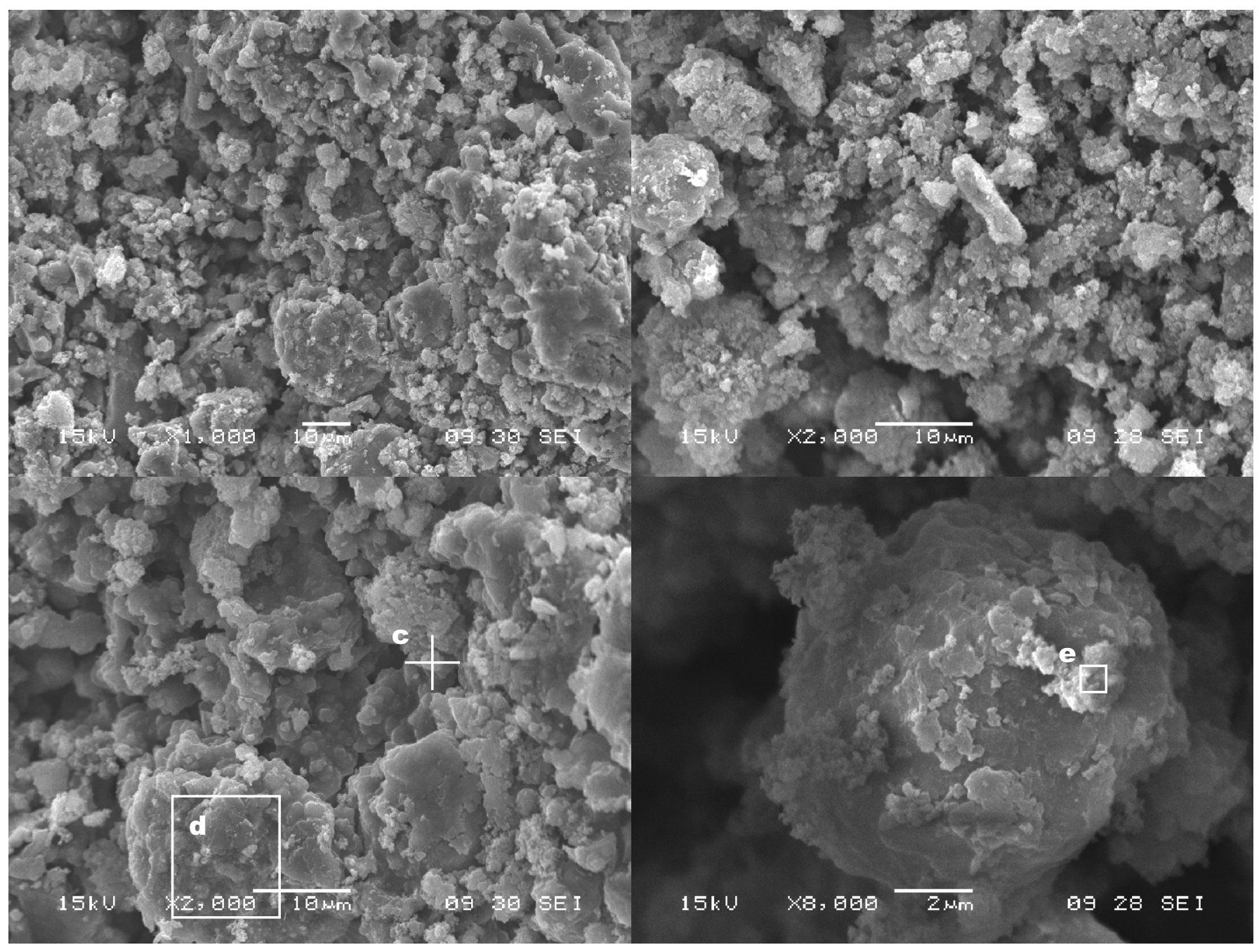

Fig. 2 


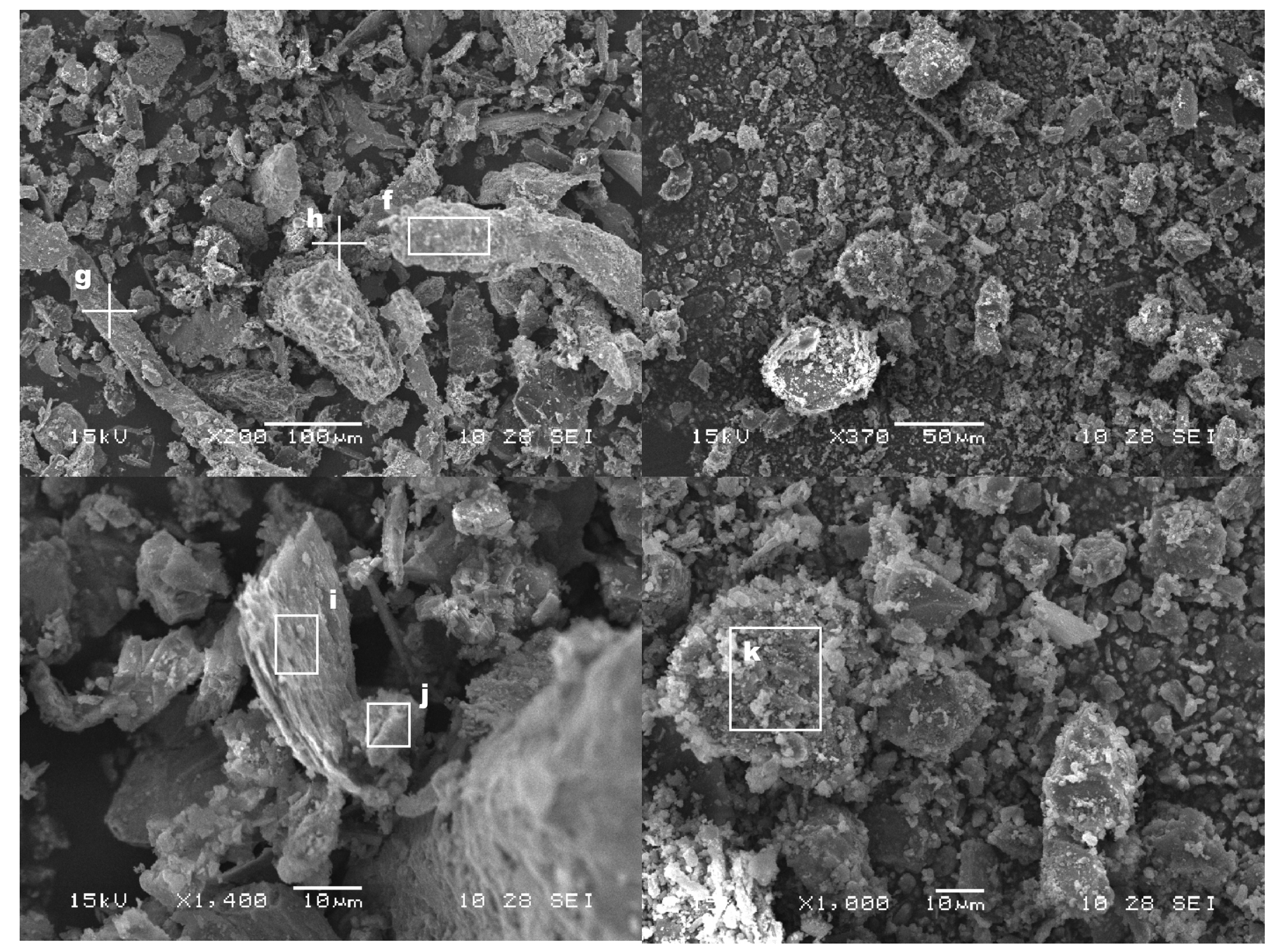

Fig. 3 


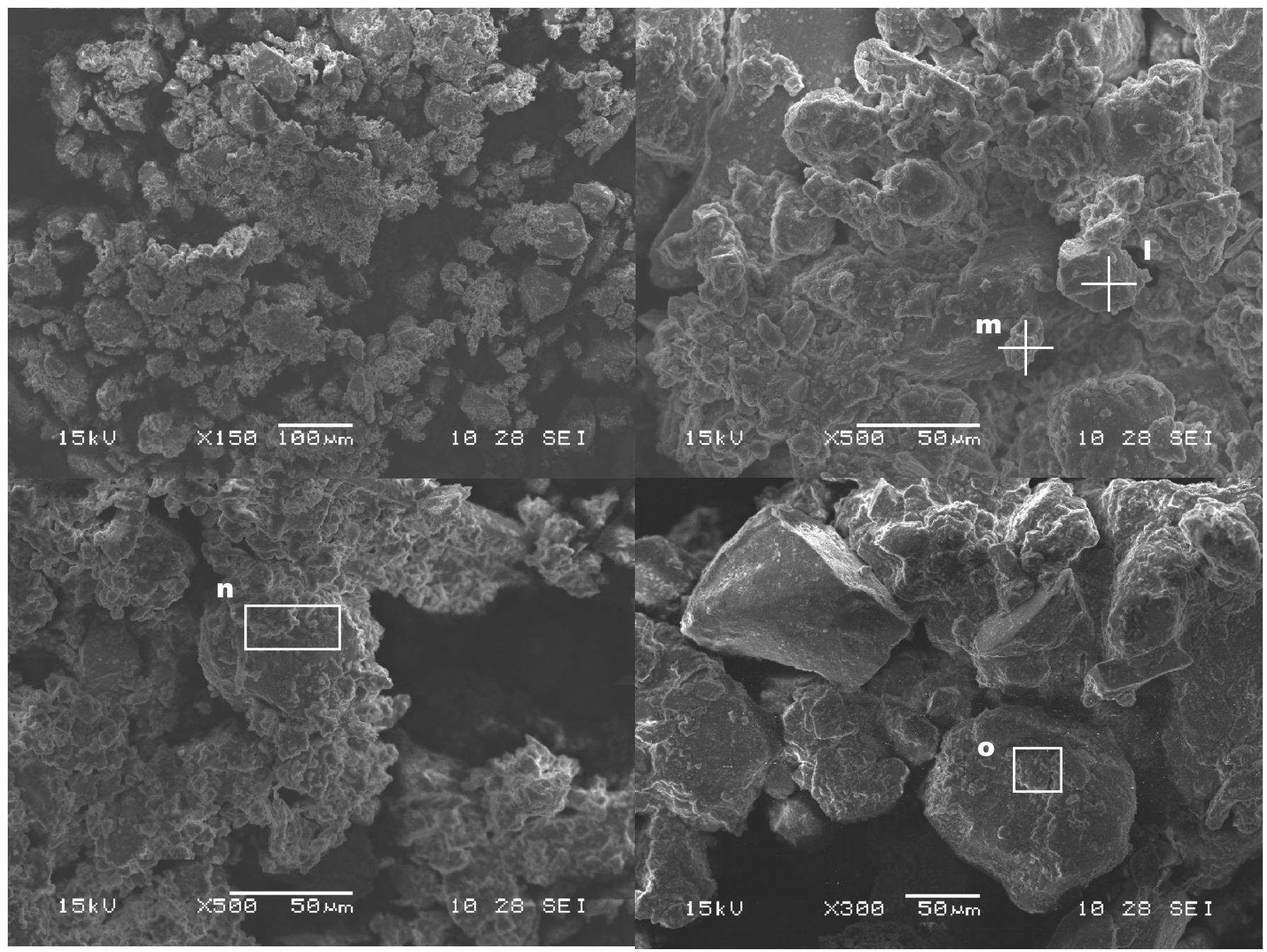

Fig. 4 


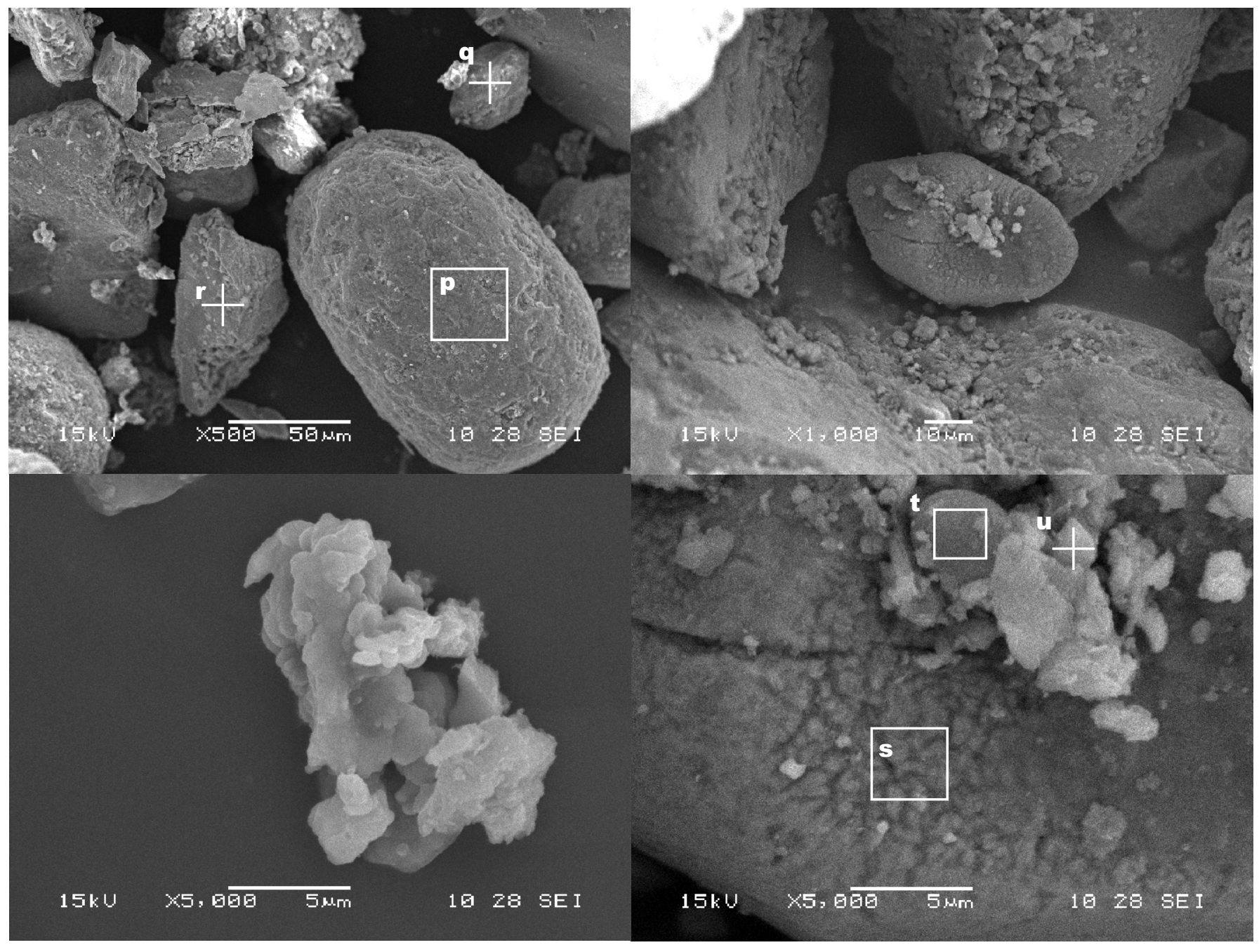

Fig. 5 


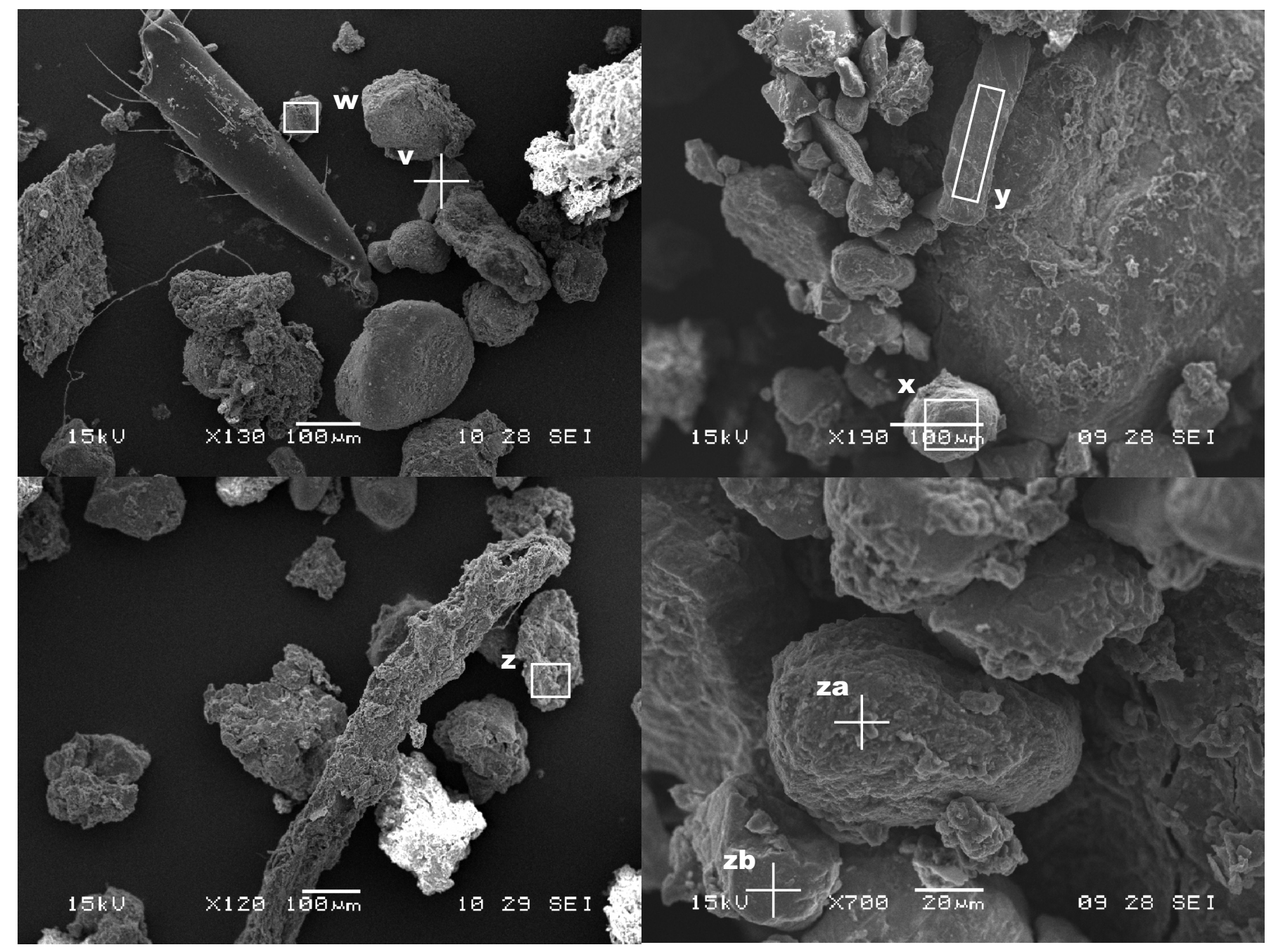

Fig. 6 